\title{
Analytical Behavior of High and Ultra-High Rise Structures Using Different Lateral Load Carrying Systems
}

\author{
Ramy Mohammed Abd El Rahman Aly Aggag ${ }^{1}$, Prof. Dr. Mohamed Basil Emara ${ }^{2}$ and Dr. Mohamed \\ Amr Salama ${ }^{3}$
}

\author{
Research Scholar ${ }^{1}$, Professor ${ }^{2-3}$ and Lecturer $^{3}$ \\ Department of Civil Engineering
}

Faculty of Engineering (Mataria), Helwan University

Cairo

Egypt

\begin{abstract}
A real residential building consists of 15 stories which have been built in Cairo - Egypt is studied against lateral loads, also the linear analysis repeated for the same building after increasing the number of repeated stories reaching 30, 45 and 60 stories, using two lateral load resisting systems which are outriggers and bracing systems. The ETABS 2015 program is used to analyze all the buildings by the Egyptian, European and American codes. The most common high rise buildings in Egypt consists of 15 to 30 stories, so linear analysis was conducted to the 30 stories building using Egyptian, European and American codes but in different region and soil type than what they were studied. Seismic demands were studied are the base shear force resulted from the seismic loads on the structure, the inter-story drift between the stories of the structure, the maximum displacement of the structure and the weight of reinforced concrete and steel bracing in the structure. Finally, the nonlinear analysis applied to the 30 stories building. It is concluded that the Egyptian code gives base shear, maximum displacement and total weight of the building more than that of the European and the American codes, the buildings contain outriggers and belts system have more weight than building contain bracing system while the both have the safety requirements for the building, the total weight of the building increased slightly by changing the region of the building from the seismic region to higher seismic region while the quantity of the lateral load resisting system increased extremely, finally the nonlinear analysis of the buildings give near results to the linear analysis so the linear analysis can be dependable.
\end{abstract}

Key Words: High rise buildings, Lateral Loading Systems, Outrigger and Belts, Bracing, Lateral Loads, Earthquakes.

\section{INTRODUCTION}

In the recent years, Civilized societies desired to have high and ultra-high rise buildings to show their high extent of knowledge in civil engineering technology, to encourage the tourism in their countries and to increase the habitants in prime city locations by vertical extension. Lateral loads are the main problem facing these structures. Codes of many countries describe different methods for calculating and analyzing loads on buildings and also give provisions and limitations for loads and displacements due to lateral loads which will be discussed in this thesis.

Lateral load resisting systems are used to resist lateral loads in high and ultra-high rise buildings such as frames, shear walls, bracing and dampers. In Egypt, the frames and shear walls are the most used lateral load resisting systems while the other systems are rarely to be used, So in this thesis linear and nonlinear structural analysis will be conducted to high rise building contain lateral load resisting systems other than frames and shear walls, and the analysis will be prepared using different codes requirements and provisions. 


\section{OBJECTIVES AND SCOPE}

In this thesis, structural analysis for buildings consists of 15,30,45 and 60 storeys were made by ETABS (Extended Three Dimensional Analysis of Building Structures) Program to fulfill these objectives:

1. A review of the different structural systems used in constructing high and ultra-high rise buildings will be conducted.

2. The role of frames, structural (shear) walls, outriggers and lateral bracing systems in resisting lateral loads will be studied and presented.

3. Linear and nonlinear structural analysis of selected case study involving different configurations and specifications of these systems will be performed using Egyptian, European and American codes.

4. Different codes requirements for evaluating lateral loads acting on such structures will be discussed.

5. Different code limitations on lateral deformations will be checked against the suggested configurations.

\section{Case study}

\subsection{Case study configuration}

The case study is a residential structure built in Cairo- Egypt consists of 15 storeys. The building consists of 15 storeys which are 2 basement, ground storey,1st storey, 8 repeated storeys, 10th storey, roof storey and upper roof rooms. The case study is shown in figure 1 .

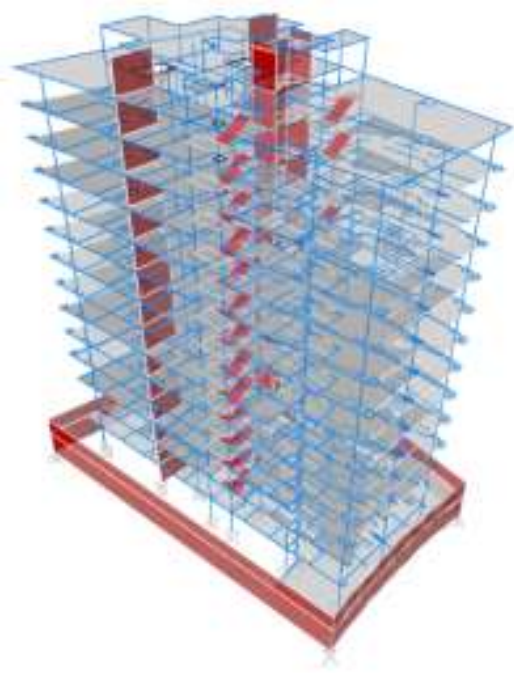

Figure 1: 3D view for the 15 storeys building which built in the reality

\subsection{The linear analysis of case study}

Linear analysis is applied on the case study and also after increasing number of storeys of the building to be 30,45 and 60 storeys with specifications of Egyptian code for Loads and Forces 2012 (ECLF 2012), Eurocode 8: Design of structures for earthquake resistance 2004 (Eurocode-8-2004) and American Society of Civil Engineering 2010 (ASCE07-10). Linear analysis applied using response spectrum method.

The building contains shear wall frame system that resist lateral loads. In this thesis, the building design was checked against lateral loads acting on it and then the structural analysis was prepared for the building after increasing the number of storeys to be 30, 45 and 60 storeys. The analyzed buildings had the same architectural plans except that the number of typical storey increased.

The structural design of these buildings was prepared in two steps. The primary stage which is design the building according to the vertical loads only, and then the secondary stage which is adding lateral loads and ensure withstanding these loads by shear wall frame system, and if shear wall frame system couldn't hold out the lateral loads, two other lateral load resisting systems were added which are the outrigger and belt system and the bracing system, and each of these systems used individual in addition to the shear wall frame system. The structural analysis of all buildings prepared by The ETABS program.

The outrigger and belt system is made up of reinforced concrete and it can be fabricated in site as like as beams, so this system can be built easily. Specific storeys in the building used to retain outriggers and belts (outriggers and belts storeys), and a lot of researches were conducted to identify the optimum position for these storeys, and many of these researches agreed on putting these specific storeys in positions which divide the height of the building in to equal parts having the same number of storeys. The 
number of outriggers and belts storeys depend on the magnitude of lateral loads acting on the building, and this number of outriggers and belts storeys determined by trial-and-error approach as the following: Adding one outriggers and belts storey in the building and run the structural analysis, and if this outriggers and belts storey didn't give the building sufficient stiffness to resist the lateral loads then another outriggers and belts storey will be added and run the structural analysis and so on.

The outriggers and belts were put and arranged in each storey according to the architectural design, and these outriggers and belts replace some beams so that the beams which connect between some columns and shear walls each other will be replaced by belts, and the beams which connect columns or shear walls with cores will be replaced by outriggers.

The clear height of the storey contains outriggers and belts is small due to outriggers and belts have large depth, which make the storey unusable and the architects reject it, so that the height of this storey larger than the other storeys to give it acceptable clear height, and after the finish of the construction, an artificial cladding will be used to cover the outriggers and belts from the bottom. The width of the outriggers and belts is large to withstand the shear loads, preventing nesting of the concrete and to facilitate the fabrication of it.

The bracing system used is made up of steel, and the X-bracing type is used which consists of two steel I-beam sections intersecting each other in every storey. The X-bracing type is chosen because it can be installed easily using small amount of bolts and welding. The steel I-beam sections have high stiffness comparable with their small area. The bracing system connect columns and shear walls with each other, and this system used beside the shear wall frame system to resist lateral loads. The bracing system connect columns and shear walls at joints ( the point of intersection between columns or shear walls with beams or slabs), so the connection will be more stiff and the sway of storeys decreased.

The composite columns or composite shear walls were connected with the steel bracing at the steel section inside the composite column or the composite shear wall, using welding and bolts, then the concrete is casted in the composite column or the composite shear wall. When concrete column or concrete shear wall is connected steel bracing, a steel section is installed inside the column or the shear wall had the same section of the steel bracing in the first, then the connection is made between the installed steel section and the steel bracing using welding and bolts, and finally the concrete is casted in the column or the shear wall.

The bays between columns and shear walls inside the building were crowded by obstacles such as corridors or door openings, so the bracing system made at the outer sides of the building and this type of bracing system called outer bracing system. There is no columns or shear walls at the front side of the building to put outer bracing between them, and the outer bracing at the back side wasn't enough to resist lateral loads alone, so the five columns which were located near to the front side were moved to outside, to be at the front side to give the possibility of making the outer bracing at the front side of the building.

The trial-and-error approach was used to determine the number of bays used at each side of the building to make the outer bracing and the amount of steel sections used in the outer bracing, depending on the amount of the lateral loads acting on the building. The connections between steel bracing with each other were made using welding and bolts.

\subsubsection{Numerical results discussion}

The analysis results in terms of weight of the structure, the base shear and the maximum displacement are presented.

\subsubsection{The weight of the case study buildings according to the three codes used}

When the base shear increased, the volume of the lateral load resisting elements increased causing increase in the total weight of the building. The ECLF 2012 code had the largest base shear then the Eurocode-8-2004 code and finally the ASCE07-10 code had the smallest base shear. So the weight of building designed according to the ECLF 2012 code is the greatest after that the building designed according to the Eurocode-8-2004 code and finally the building designed according to ASCE07-10.

The weight of the 15, 30, 45 and 60 storeys buildings according to the ECLF 2012, the Eurocode-8-2004, and the ASCE07-10 codes is shown in table 1. The Egyptian code gave weight greater than Eurocode-8-2004 code and ASCE7-2010 code by approximately $2 \%$ and $6 \%$ respectively in the 30 storeys building contain outriggers and belts system, while The Egyptian code gives steel bracing weight approximately equal two times that of Eurocode-8-2004 code in the 30 storeys building contain outer bracing system.

The Egyptian code gave weight greater than Eurocode-8-2004 code and ASCE7-2010 code by approximately 14\% and $13 \%$ respectively in the 45 storeys building contain outriggers and belts system, while The Egyptian code gave steel bracing weight extremely larger than that of Eurocode-8-2004 code in the 45 storeys building contain outer bracing system. 
The Egyptian code gives weight greater than Eurocode-8-2004 code and ASCE7-2010 code by approximately $13 \%$ and $20 \%$ respectively in the 60 storeys building contain outriggers and belts system, while The Egyptian code gives steel bracing weight extremely larger than that of Eurocode-8-2004 code and that of ASCE7-2010 code in the 60 storeys building contain outer bracing system due to the allowable inter storey drift of the Eurocode-8-2004 code and that of ASCE7-2010 code is larger than that of the Egyptian code.

The cost of the building increased as its weight increased, so the building designed according to the ECLF 2012 code had the greatest cost.

Table 1: The weight of the 15, 30, 45 and 60 storeys buildings according to the ECLF 2012, Eurocode-8-2004, and the ASCE07-10 codes

Quantites

\begin{tabular}{|c|c|c|c|c|c|c|c|c|c|c|}
\hline Number of Stories & 15 Stories & \multicolumn{3}{|c|}{30 Stories } & \multicolumn{3}{|c|}{45 Stories } & \multicolumn{3}{|c|}{60 Stories } \\
\hline Structural System & & Outrigers System & \multicolumn{2}{|c|}{ Outer Bracing System } & Outriggers Spstem & \multicolumn{2}{|c|}{ Outer Bracing System } & Outriggers System & \multicolumn{2}{|c|}{ Outer Brating System } \\
\hline Code & $\begin{array}{l}\text { R.C Wregets } \\
\text { [ten| }\end{array}$ & ReWeight (ton) & $\begin{array}{l}\text { R.CWeght } \\
\text { (ton) }\end{array}$ & $\begin{array}{c}\text { Basding Streel Weight } \\
\text { (ton) }\end{array}$ & Ric Weight (too) & $\begin{array}{l}\text { R.C Weight } \\
\text { (ton) }\end{array}$ & $\begin{array}{l}\text { Bncing Steel } \\
\text { Weght (tan) }\end{array}$ & $\begin{array}{l}\text { R.CWeight } \\
\text { (ton) }\end{array}$ & $\begin{array}{c}\text { RCWeight } \\
\text { (ton) }\end{array}$ & $\begin{array}{c}\text { Broding Steet Weight } \\
\text { (tos) }\end{array}$ \\
\hline ECLF 2012 & 8006.7 & 19765.5 & 18554.38 & 818 & 39790.13 & 33582.72 & 397.02 & $67856: 82$ & 61584825 & 2037.108 \\
\hline Eurocodes-2004 & 8006,7 & 19366.34 & 18853.4 & $41 \pi$ & 34963.8 & 33124.94 & 118.15 & 6017053 & 59840287 & 758.065 \\
\hline ASCED7-10 & 8006,7 & & 18510.57 & & & 32547.38 & & 566549 & 5597206 & 59.87 \\
\hline
\end{tabular}

\subsubsection{The maximum base shear results of the case study buildings according to the three codes used}

The base shear for the all buildings in the $\mathrm{X}$ and $\mathrm{Y}$ directions were shown in figure 2 and figure 3 respectively. The Egyptian code gives base shear greater than Eurocode-8-2004 code and ASCE7-2010 code by approximately $11 \%$ and $15 \%$ respectively in the 15 storeys building which is a little difference.

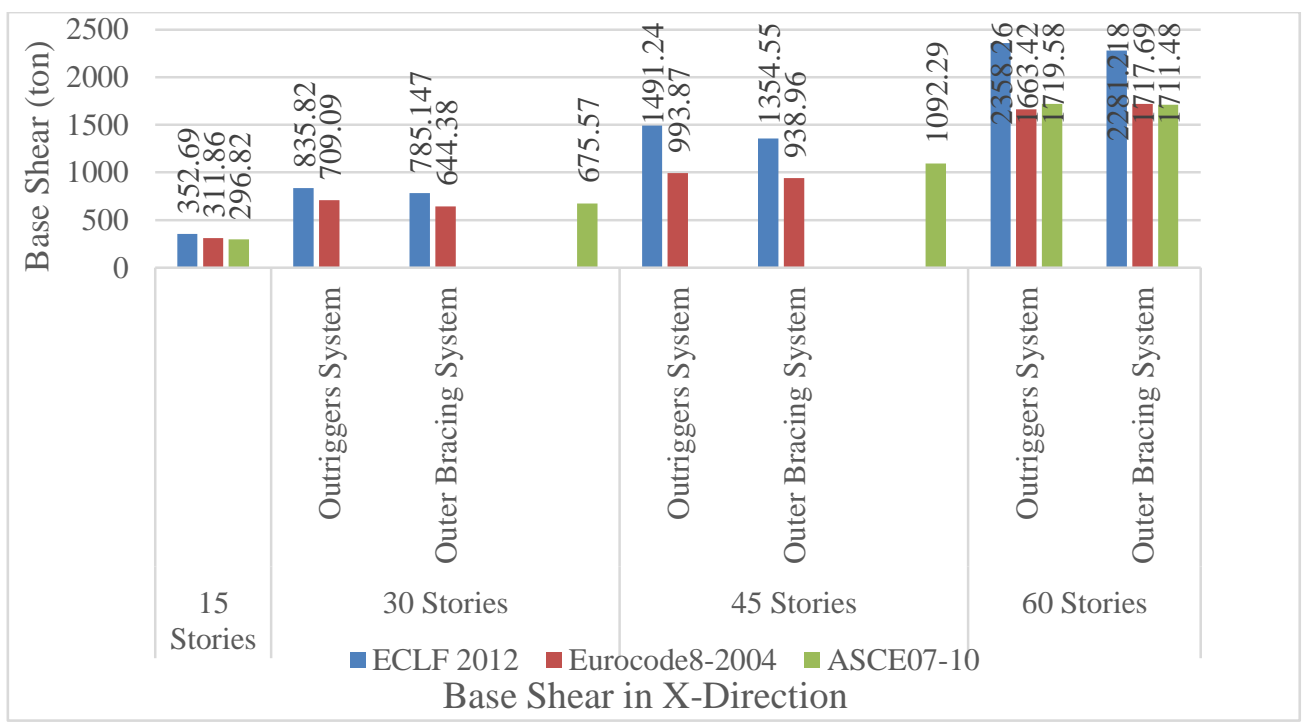

Figure 2: The base shear of the 15, 30, 45 and 60 storeys buildings in X-direction according to the ECLF 2012, Eurocode8-2004, and the ASCE07-10 codes 
International Journal of Advances in Scientific Research and Engineering (ijasre), Vol 5 (5), May-2019

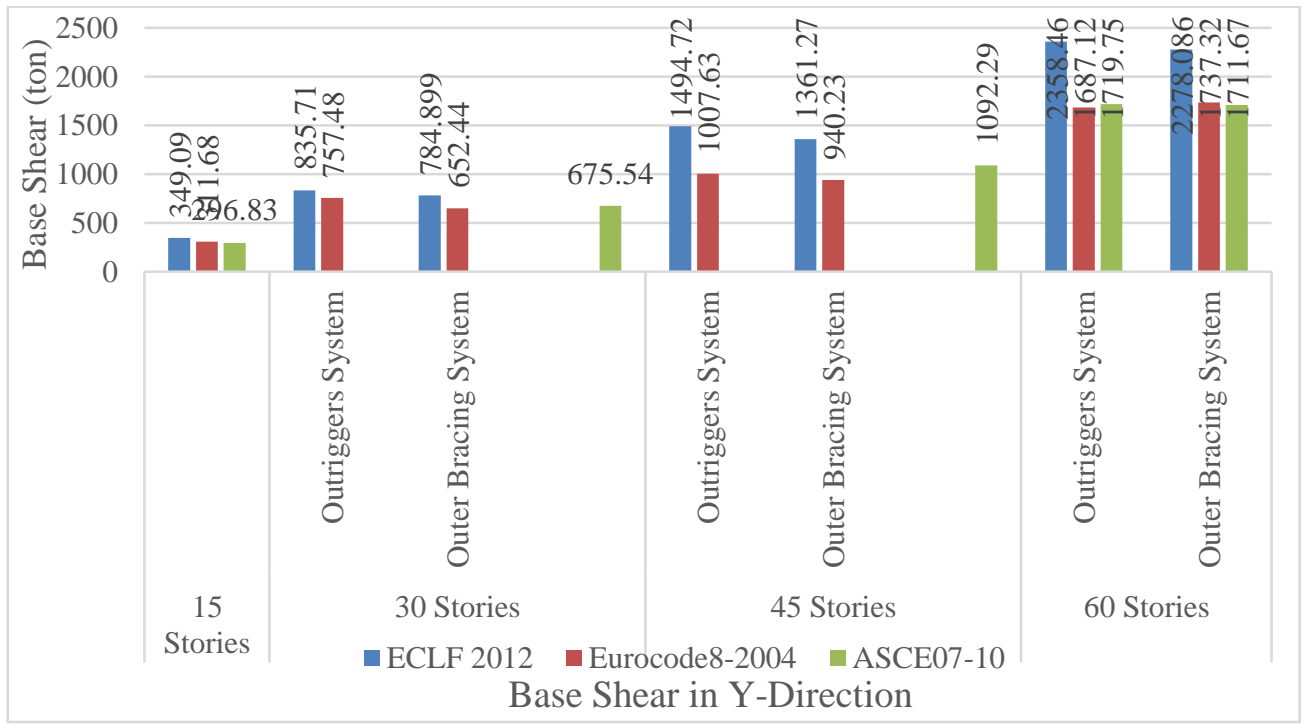

Figure 3: The base shear of the 15, 30, 45 and 60 storeys buildings in Y-direction according to the ECLF 2012, Eurocode8-2004, and the ASCE07-10 codes

The Egyptian code gives base shear greater than Eurocode-8-2004 code and ASCE7-2010 code by approximately 15\% and 19\% respectively in the 30 storeys building contain outriggers, while The Egyptian code gives base shear greater than Eurocode-8-2004 code and ASCE7-2010 code by approximately $17 \%$ and 14\% respectively in the 30 storeys building contain outer bracing system.

The Egyptian code gives base shear greater than Eurocode-8-2004 code and ASCE7-10 code by approximately 33\% and 27\% respectively in the 45 storeys building contain outriggers and belts system, while The Egyptian code gives base shear greater than Eurocode-8-2004 code and ASCE7-2010 code by approximately 30\% and 18\% respectively in the 45 storeys building contain outer bracing system. The Egyptian code gives base shear greater than Eurocode-8-2004 code and ASCE7-2010 code by approximately $29 \%$ and $27 \%$ respectively in the 60 storeys building contain outriggers and belts system, while The Egyptian code gives base shear greater than Eurocode-8-2004 code and ASCE7-2010 code by approximately 24\% and 25\% respectively in the 60 storeys building contain outer bracing system.

In the three Codes, the buildings contain outer bracing system gives the lower base shear force than the buildings contain outriggers and belts system because the outer bracing system has weight lower than the outriggers and belts system.

\subsubsection{The maximum storey displacement results of the case study buildings according to the three codes used}

The maximum displacement of the buildings in the $\mathrm{X}$ and $\mathrm{Y}$ directions is shown in figure 4 and figure 5 respectively.

In the 15 Storeys building, the maximum displacement from the ECLF 2012 is greater than that from the Eurocode-8-2004 and ASCE7-10 by approximately $9 \%$ and $23 \%$ respectively. In the 30 storeys building contain outrigger and belt system, the maximum displacement due to the ECLF 2012 is greater than that from the Eurocode-8-2004 by approximately $4 \%$ and smaller than that from and ASCE7-10 by approximately 3\% respectively. While in the 30 storeys building contain outer bracing system, the maximum displacement due to the ECLF 2012 is greater than that from the Eurocode-8-2004 and ASCE7-10 by approximately $11 \%$ and $10 \%$ respectively.

In the 45 storeys building contain outrigger and belt system, the maximum displacement due to the ECLF 2012 is greater than that from the Eurocode-8-2004 by approximately 7\% and smaller than that from and ASCE7-10 by approximately 14\%. While in the 45 storeys building contain outer bracing system, the maximum displacement due to the ECLF 2012 is greater than that from the Eurocode-8-2004 and ASCE7-10 by approximately 3\% and 17\% respectively.

In the 60 storeys building contain outrigger and belt system, the maximum displacement due to the ECLF 2012 is greater than that from the Eurocode-8-2004 and ASCE7-10 by approximately 3\% and 10\% respectively. While in the 60 storeys building contain outer bracing system, the maximum displacement due to the ECLF 2012 is greater than that from the Eurocode-8-2004 and ASCE7-10 by approximately $3 \%$ and $2 \%$ respectively. 


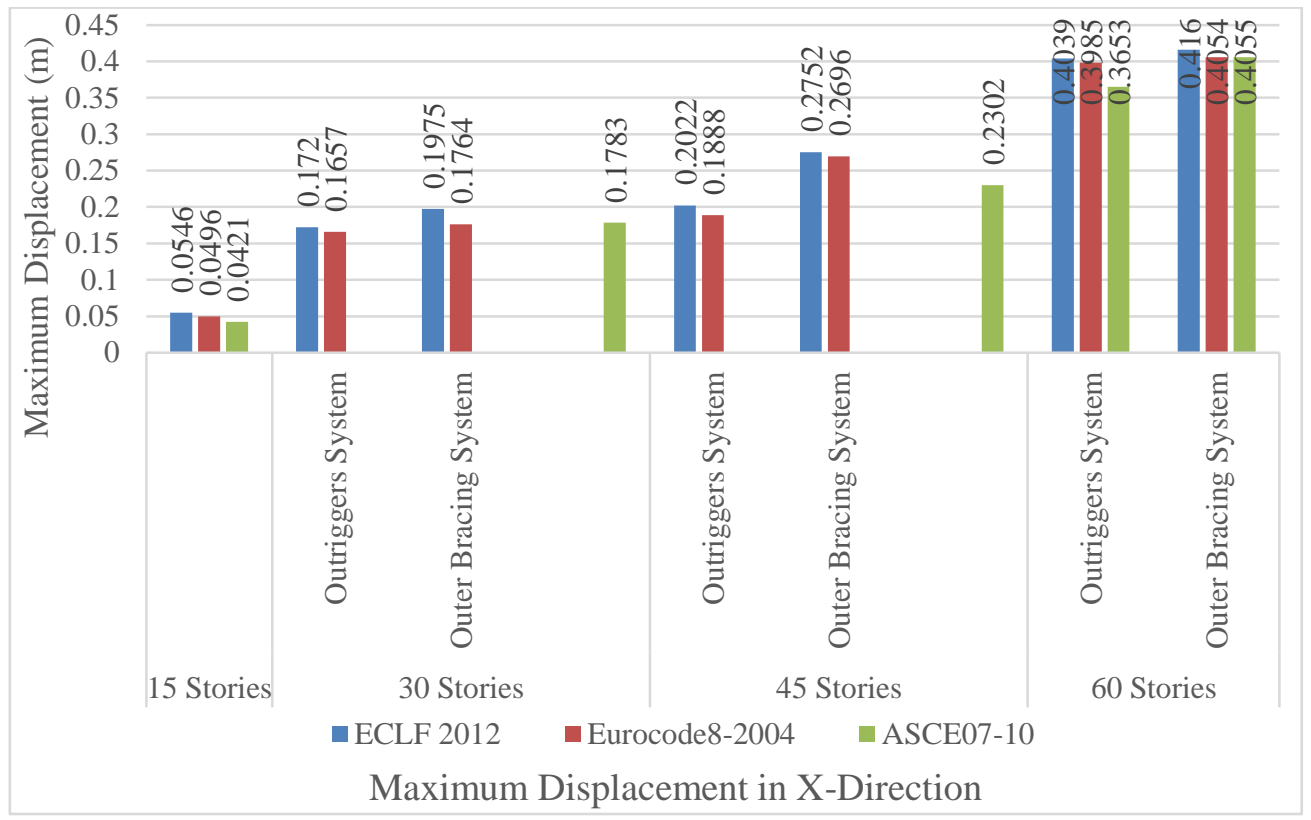

Figure 4: The maximum displacement of the 15, 30, 45 and 60 storeys buildings in X-direction according to the ECLF 2012, Eurocode-8-2004, and the ASCE07-10 codes

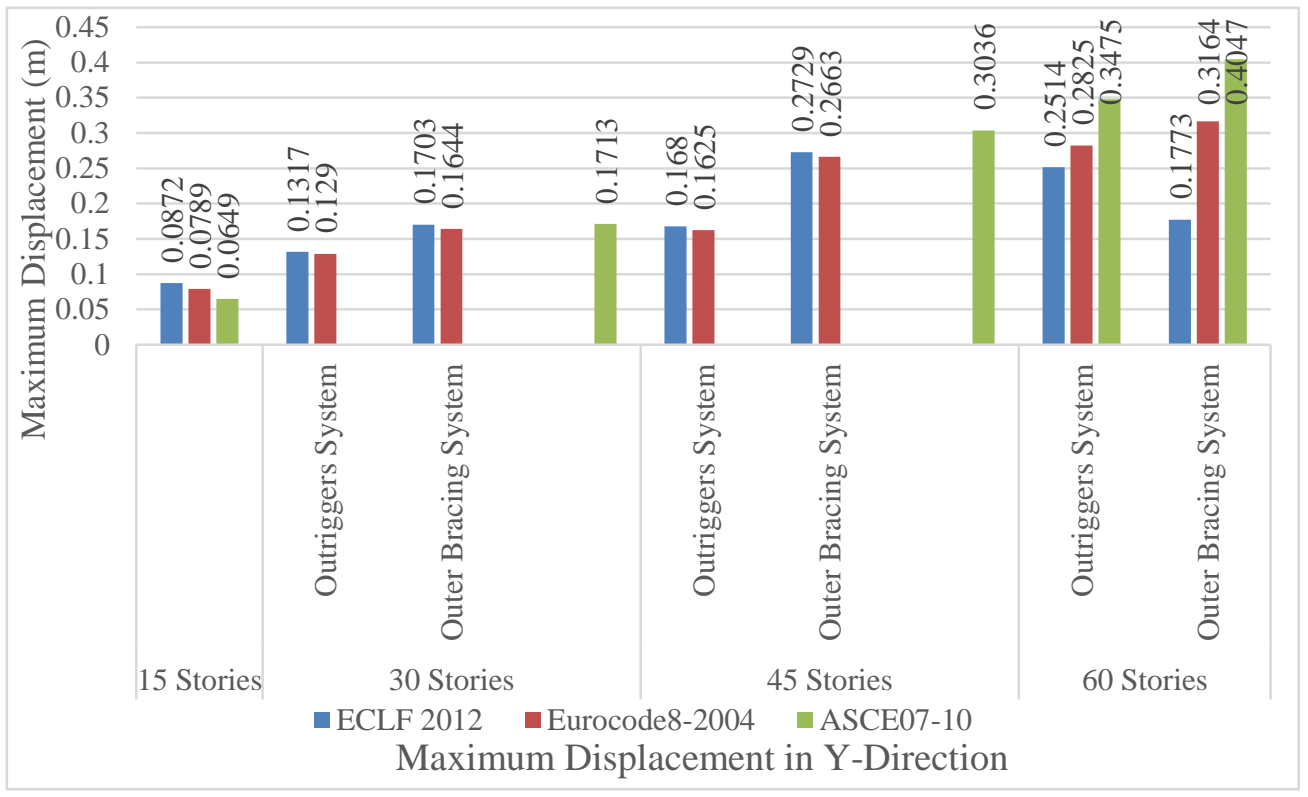

Figure 5: The maximum displacement of the 15, 30, 45 and 60 storeys buildings in Y-direction according to the ECLF 2012, Eurocode-8-2004, and the ASCE07-10 codes

\subsection{The linear analysis of the 30 storeys building after changing the region and the soil type}

Linear analysis is applied on the case study after increasing number of storeys of the building to be 30 storeys assuming that the region was changed from the third region to the forth region and the soil changed from type $\mathrm{C}$ to type $\mathrm{D}$ using the same three codes noted before, so that the earthquake loads increased.

\subsubsection{Numerical results discussion}

The weight of the building, base shear and maximum displacement of the 30 storeys buildings in the $3^{\text {rd }}$ region and soil type $\mathrm{C}$ were compared with the 30 storeys buildings built in the $4^{\text {th }}$ region and soil type $\mathrm{D}$ according to the three codes used. 


\subsubsection{The weight of the 30 storeys buildings located in the 3rd and 4th region according to the three codes} used

The weight of the 30 storeys buildings located in the 3rd and 4th region according to the ECLF 2012, the Eurocode-8-2004, and the ASCE07-10 codes is shown in table 2.

By changing the region of the 30 storeys building from the third region to the forth region, the building contain outriggers and belts system, The Egyptian code and the Eurocode-8-2004 code gives approximately 5\% more weight while the ASCE7-2010 code gives approximately $1 \%$ more weight. The buildings contain outer bracing system, The Egyptian code gives approximately $263 \%$ more steel bracing weight and the Eurocode-8-2004 code gives approximately 133\% more steel bracing weight.

The ECLF 2012 has the maximum weight in all cases after that the Eurocode-8-2004 and finally the ASCE7-10.

\subsubsection{The maximum base shear results of the 30 storeys buildings located in the 3rd and 4th region according} to the three codes used

The base shear for the all buildings in the $\mathrm{X}$ and $\mathrm{Y}$ directions studied were shown in figure 6 and figure 7 respectively.

By changing the region of the 30 storeys building from the third region to the forth region and changing the soil from type $\mathrm{C}$ to type D, the base shear increased in the Egyptian code, the Eurocode-8-2004 code and the ASCE7-2010 code by approximately $37 \%, 21 \%$ and $13 \%$ respectively the building contain outriggers and belts system, while the base shear increased in the Egyptian code, the Eurocode-8-2004 code and the ASCE7-2010 code by approximately 34\%,35\% and 9\% respectively the buildings contain outer bracing system. In the three Codes, the outer bracing system gives the lowest base shear force compared to the outriggers and belts system.

Table 2: The weight of the 30 storeys buildings located in 3rd region and 4th region according to the ECLF 2012, Eurocode-8-2004 and ASCE07-10 codes

Quantites

\begin{tabular}{|c|c|c|c|c|c|c|}
\hline Number of Stories & \multicolumn{3}{|c|}{ 30 Stories (3rd Region) } & \multicolumn{3}{c|}{ 30 Stories (4th Region) } \\
\hline Structural System & Outriggers System & \multicolumn{2}{|c|}{ Outer Bracing System } & Outriggers System & \multicolumn{2}{c|}{ Outer Bracing System } \\
\hline Code & $\begin{array}{c}\text { R.CWeight } \\
\text { (ton) }\end{array}$ & $\begin{array}{c}\text { R.C Weight } \\
\text { (ton) }\end{array}$ & $\begin{array}{c}\text { Bracing Steel Weight } \\
\text { (ton) }\end{array}$ & $\begin{array}{c}\text { R.C Weight } \\
\text { (ton) }\end{array}$ & $\begin{array}{c}\text { R.C Weight } \\
\text { (ton) }\end{array}$ & $\begin{array}{c}\text { Bracing Steel Weight } \\
\text { (ton) }\end{array}$ \\
\hline ECLF 2012 & 19765.5 & 18854.38 & 81.8 & 20765.23 & 18860.97 & 296.41 \\
\hline Eurocode8-2004 & 19386.34 & 18853.4 & 41.77 & 20302.43 & 18855.89 & 95.93 \\
\hline ASCE07-10 & & 18610.57 & 18638.75 & 18852.8 & 45.72 \\
\hline
\end{tabular}

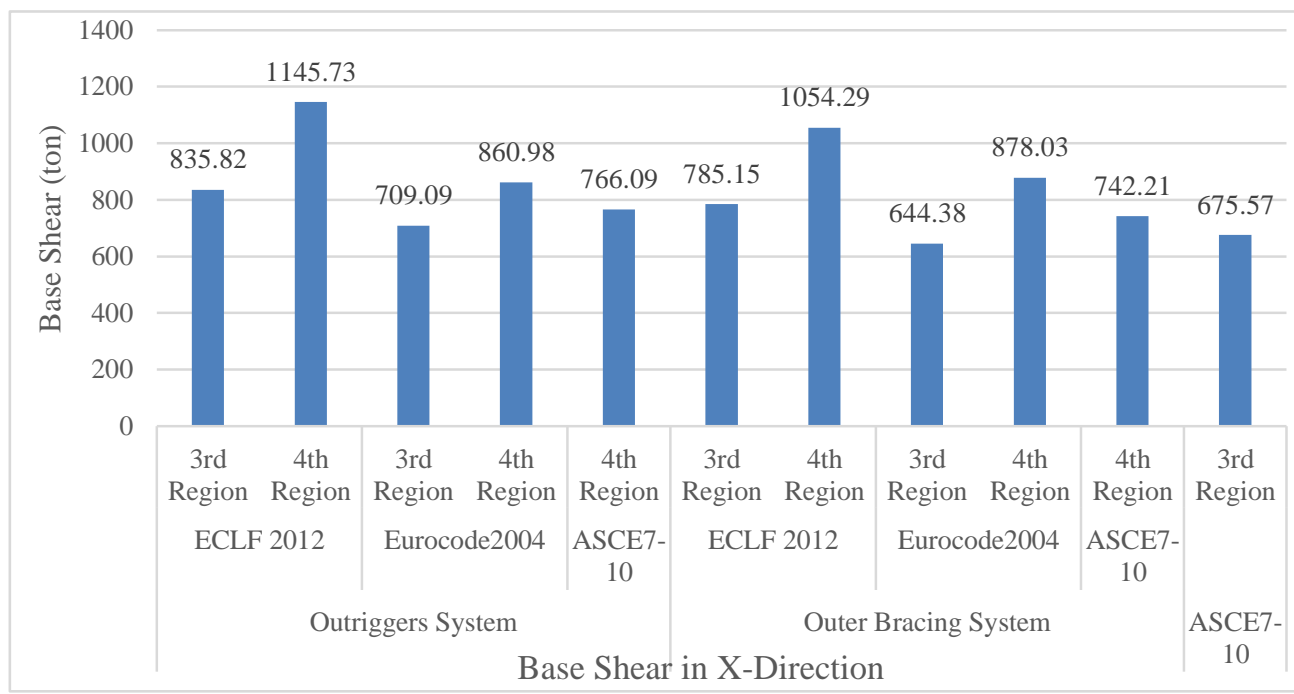

Figure 6: The base shear of the 30 storeys buildings in $X$-direction located in 3rd region and 4th region according to the ECLF 2012, Eurocode-8-2004 and ASCE07-10 codes 


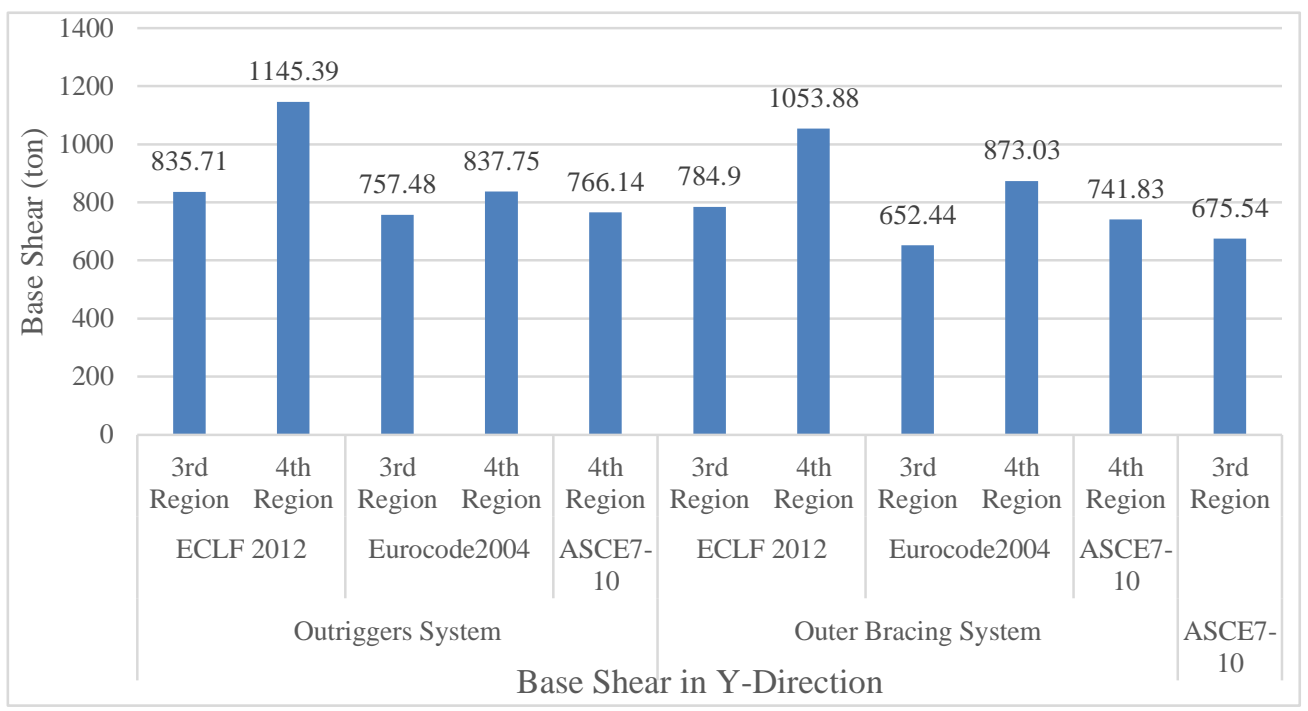

Figure 7: The base shear of the 30 storeys buildings in Y-direction located in 3rd region and 4th region according to the ECLF 2012, Eurocode-8-2004 and ASCE07-10 codes

\subsubsection{The maximum storey displacement results of the 30 storeys buildings located in the 3rd and 4th region according to the three codes used}

The maximum displacement of the buildings in the $\mathrm{X}$ and $\mathrm{Y}$ directions were shown in figure 8 and figure 9 respectively.

As the region of the 30 storeys building changed from the third region to the forth region and the soil changed from type $\mathrm{C}$ to type $\mathrm{D}$, the maximum storey displacement decreased in the buildings contain outrigger and belt system and designed according to the Egyptian code and the Eurocode-8-2004 code by approximately 34\% and 4\% respectively, while the maximum storey displacement increased in the buildings contain outer bracing system according to the Egyptian code and the Eurocode-8-2004 code by approximately $2 \%$ and $13 \%$ respectively. The maximum storey displacement increased in the buildings designed according to the ASCE7-2010 code by approximately $8 \%$.

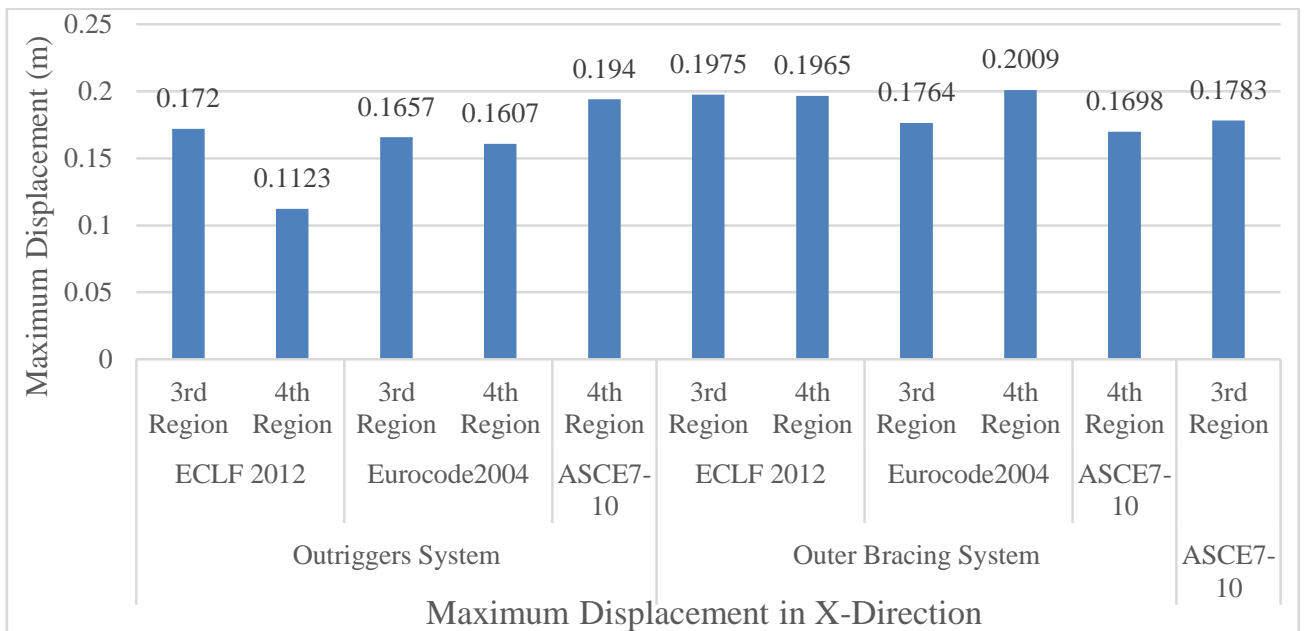

Figure 8: The maximum displacement of the 30 storeys buildings in $\mathrm{X}$-direction located in 3rd region and 4th region according to the ECLF 2012, Eurocode-8-2004 and ASCE07-10 codes 


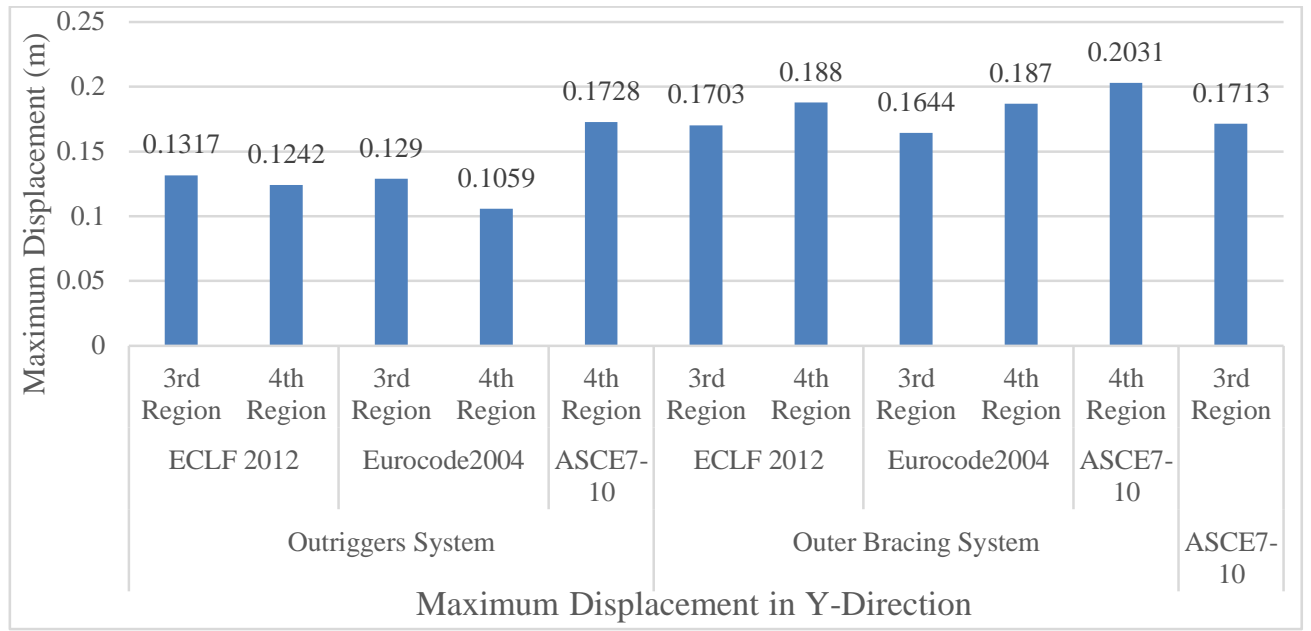

Figure 9: The maximum displacement of the 30 storeys buildings in $\mathrm{X}$-direction located in 3rd region and 4th region according to the ECLF 2012, Eurocode-8-2004 and ASCE07-10 codes

\subsection{The non-linear analysis of case study}

Non-linear analysis is applied on the case study after increasing number of storeys of the building to be 30 storeys with specifications of ECLF 2012, Eurocode-8-2004 and ASCE07-10. Non-linear analysis applied using time history method. The nonlinear structural analysis give results near to the reality so it is used to make sure of the results of the linear structural analysis which were made in the previous linear analysis.

The time history of Cairo can be observed by using ETABS program which can change the ELCENTRO time history to Cairo time history using the response spectrum of Cairo city.

\subsubsection{Numerical results discussion}

The base shear and the inter storey index were discussed and compared for the linear and the nonlinear analysis of the 30 storeys building according to the Egyptian, European and the American codes.

\subsubsection{The maximum base shear results of the 30 storeys buildings using linear and nonlinear analysis} according to the three codes used

The base shear is equal in the linear and nonlinear analysis of each code as shown in figures 10 and 11, so the point of comparison between the buildings will be the maximum storey displacement.

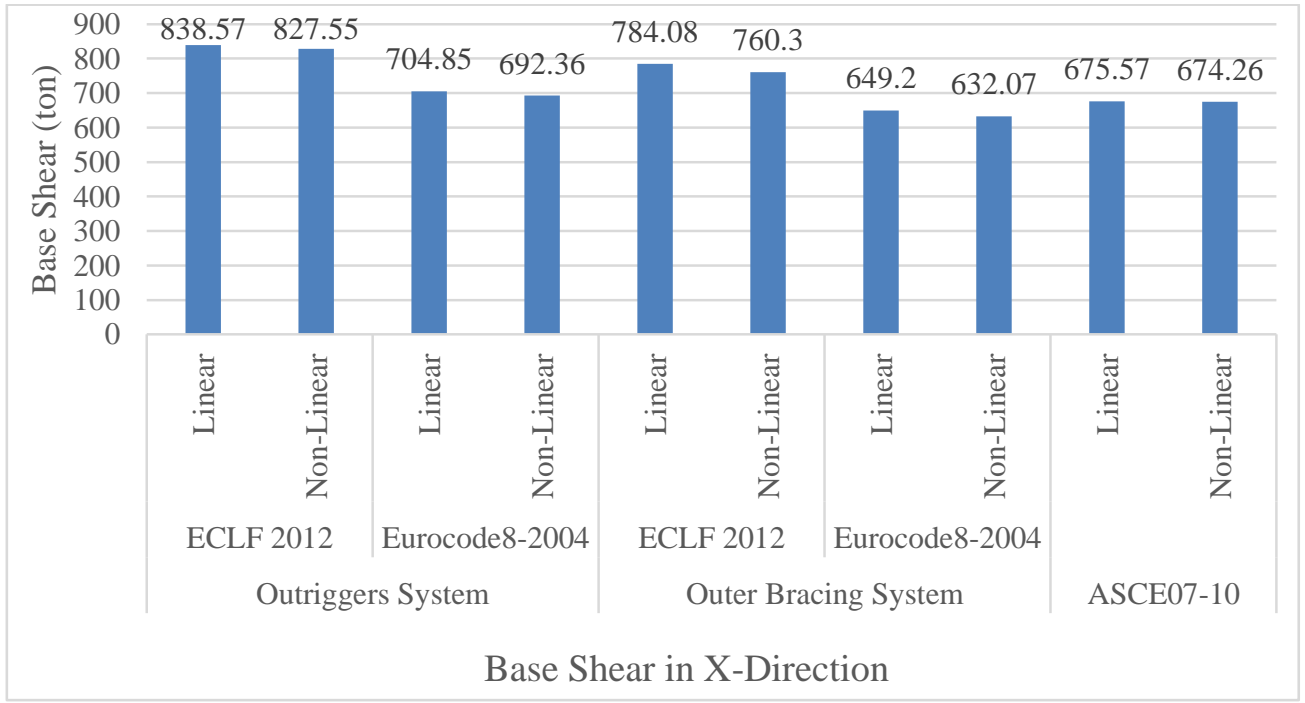

Figure 10: The base shear results of the 30 storeys buildings in X-direction using linear and nonlinear analysis according to the ECLF 2012, Eurocode-8-2004 and ASCE07-10 codes 
International Journal of Advances in Scientific Research and Engineering (ijasre), Vol 5 (5), May-2019

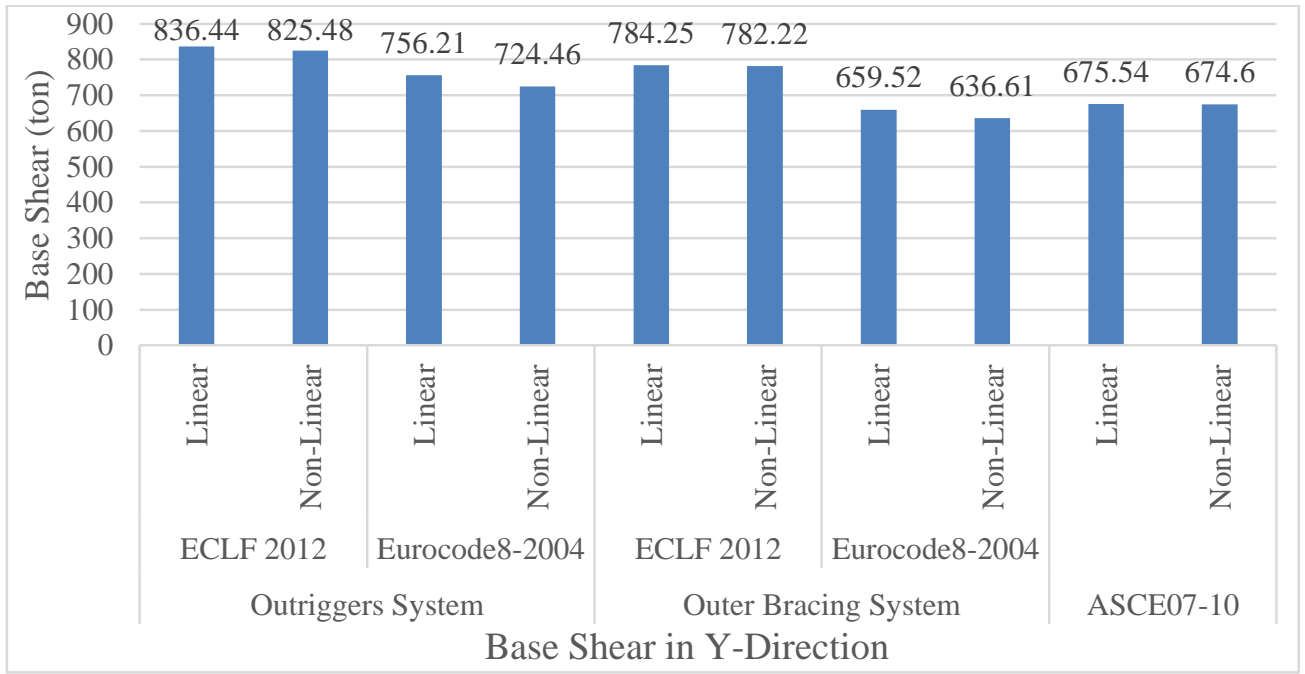

Figure 11: The base shear results of the 30 storeys buildings in $\mathrm{X}$-direction using linear and nonlinear analysis according to the ECLF 2012, Eurocode-8-2004 and ASCE07-10 codes

3.4.1.2 The maximum storey displacement results of the 30 storeys buildings using linear and nonlinear analysis according to the three codes used

The maximum displacement of the linear models is nearly equal that of the nonlinear models for each code as shown in figures 12 and 13. These means the linear analysis give nearly equal results to the nonlinear analysis, so the linear analysis is efficient and dependable.

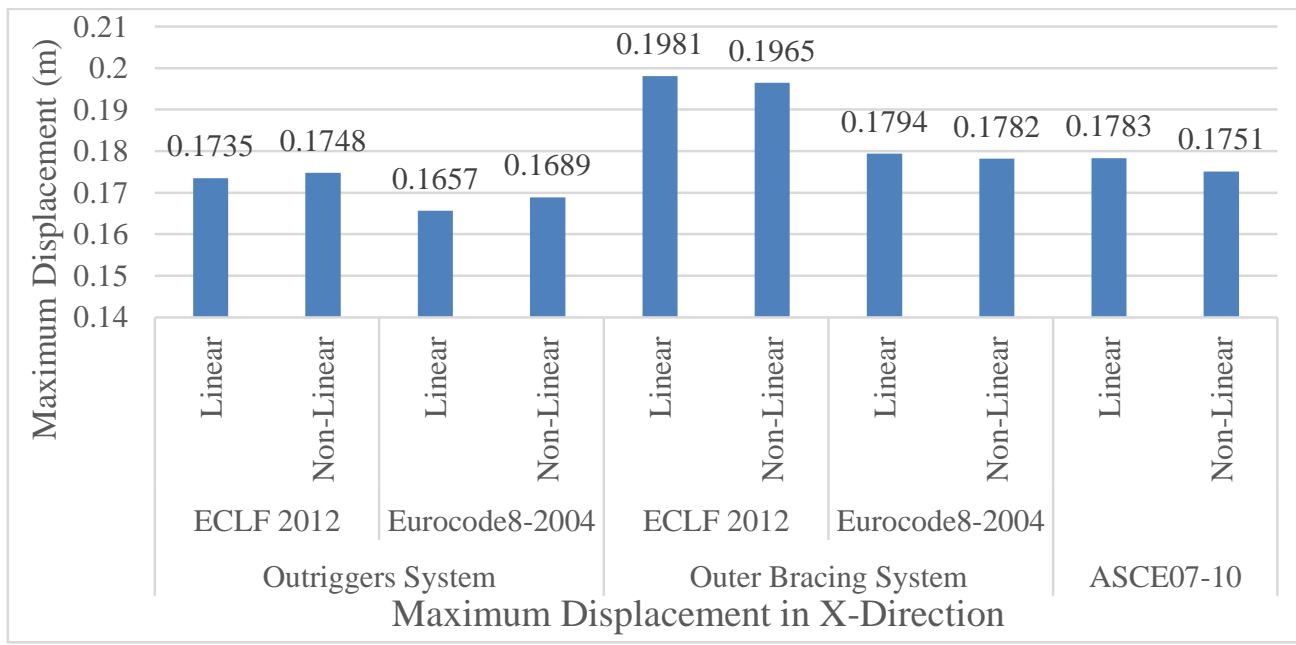

Figure 12: The maximum storey displacement results of the 30 storeys buildings in $\mathrm{X}$-direction using linear and nonlinear analysis according to the ECLF 2012, Eurocode-8-2004 and ASCE07-10 codes

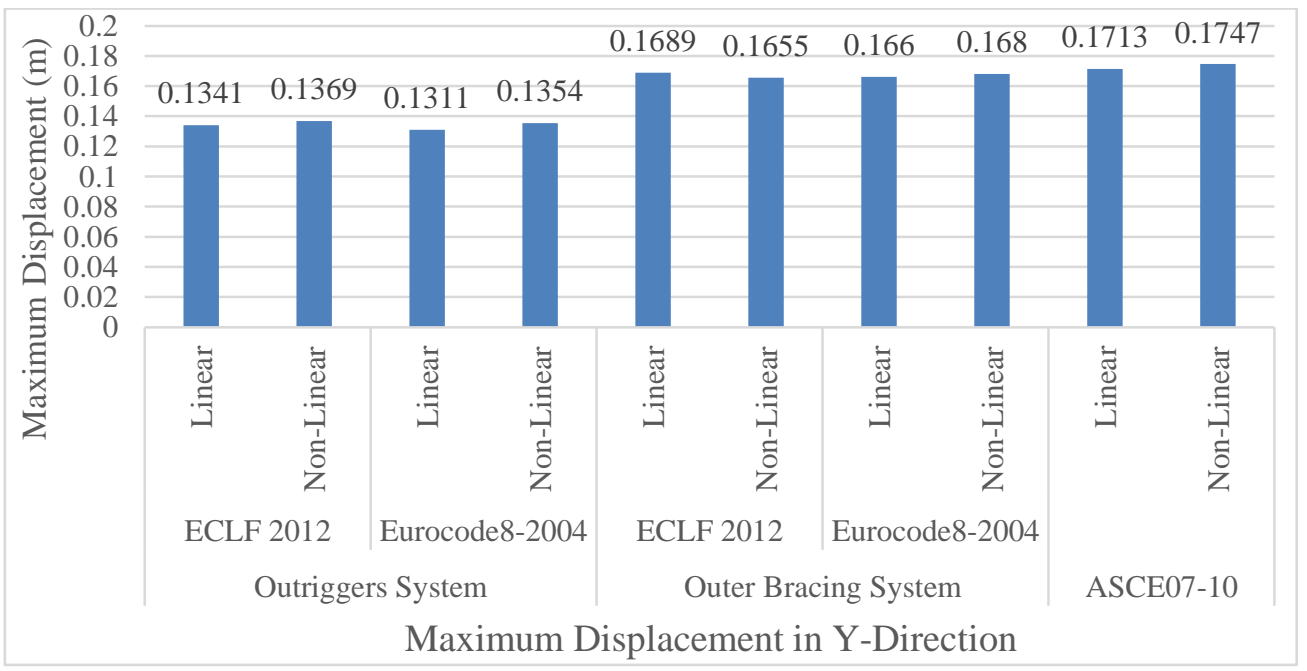

Figure 13: The maximum storey displacement results of the 30 storeys buildings in $\mathrm{Y}$-direction using linear and nonlinear analysis according to the ECLF 2012, Eurocode-8-2004 and ASCE07-10 codes 


\section{ConClusion}

- The Egyptian code gives base shear and inter storey drift greater than Eurocode-8-2004 code and ASCE7-2010 code.

- The ASCE7-2010 code gives the lowest weight of the building results.

- The beams in outriggers and belts models have more bending moment and shear force than the beams in the braced models.

- In the 30, 45 and 60 storeys buildings, the weight of the outriggers and belts building is more than that of the braced building so from the economical view, the braced buildings are better due to their low cost.

- The maximum displacement is achieved by the Egyptian code then the Eurocode-8-2004 code and finally by the ASCE72010 code.

- By changing the region of the 30 storeys building from the third region to the forth region, and changing the soil type from soil type C to soil type D, it is concluded that: The base shear increased in the Egyptian code, the Eurocode-8-2004 code and the ASCE7-2010 code by a little amount while the weight of the building increased by large amount.

- The nonlinear analysis of the buildings consists of 30 storeys buildings gives near results to the Linear Analysis so the linear analysis can be dependable.

\section{REFERENCES}

[1] ACI 318-14, American Concrete Institute Code (2005), "Building Code Requirements for Structural Concrete and Commentary.

[2] Archila, M., (2011), "Nonlinear Response of High Rise buildings: Effect of Directionally of ground motions", M.Sc. Thesis, Faculty of Engineering, The University of Britch Columbia, Canada.

[3] ASCE Standard, "Minimum Design Loads for Buildings and other Structures ASCE 7-10", American Society of Civil Engineering, Washington DC, 2010.

[4] Badabi, M. D., (2016), "Seismic performance evaluation and economic feasibility of self-centering concentrically braced frames", D.Ph. Thesis, Faculty of Engineering, The University of Akron, Ohio, USA.

[5] Bryan Stafford smith \& Alex Coull (1991), "Tall Building Structures: Analysis and Design”, New York: John Wiley \& Sons, Inc.

[6] Bungale S. Taranath, "Structural Analysis and design of Tall Buildings: Steel and Composite Structures", New York: CRC Press-Taylor \& Francis Group, 2012.

[7] Carlot, J., (2012), "Effects of Tuned Mass damper on Wind-Induced motions in tall buildings", M.Sc. Thesis, Faculty of Engineering, Massachusetts Institute of Technology, Massachusetts, USA.

[8] CEN/TC 250 Technical Committee "Eurocode-8-2004: Design of Structures for Earthquake Resistance-part1: General Rules, Seismic Actions and Rules for Buildings" Final Draft Ref. No, prEN 1998-1:2003 E, CEN, Brussels, December, 2003.

[9] Consulting Engineering Bureau (C.E.B) office, 31 Fallah st., Mohandessen, Giza, Egypt.

[10] ECLF 201 permeant Committee, "ECLF 201:2011: Egyptian Code of Calculating Loads and Forces in structural work and masonry" HBRC, Giza, 2011.

[11] Ismail, N., (2013), "Comparative study of structural systems subjected to seismic loads considering different codes", M.Sc. Thesis, Faculty of Engineering, Cairo University, Giza, Egypt. 